\title{
European Multi-Level Governance
}

\author{
Florina Bran ${ }^{1}$, Dumitru Alexandru Bodislav ${ }^{1}$ and Carmen Valentina Rădulescu ${ }^{1}$
}

\begin{abstract}
This paper represents an overview of the concept of multi-level governance and the approach delivered on innovation at European level with the purpose of helping and empowering researchers and businesses to thrive in a technologically advanced economy. The concept of multi-level governance derives from the analysis of the institutional framework for the development of Community policies and the Community political process. This stems from the presumption that the Community governance system has a high degree of differentiation and integration both vertically and horizontally. The multi-level governance model illustrates how certain competences of the national state are transferred to the supranational level or to the public or private sub-national authorities. Within this model, we can meet both supranational actors and actors at national, regional or local levels. This type of governance is characterized by the existence of a limited number of authorities, divided so as to be able to perform more functions, excluding their overlapping to exercise exclusively competences on delimited territories. Multi-level governance in innovation is characterized by a national transition as a unique place for the development and implementation of innovation policy, both at supranational and sub-national levels.
\end{abstract}

Keyword: multi-level governance, European Union, development, social cohesion, institutions

\section{Introduction}

Multi-level governance is the coordinated action of the Union, the Member States and local and regional authorities, based on the principles of subsidiarity, proportionality and partnership, embodied in a functional and institutionalized operation designed to draw up and implement Union policies European. Multi-level governance can be seen and interpreted as a continuous bargaining system between different government levels, and outlines the ways in which supranational, national, regional, and local governments are involved in public policy networks.

Seen from a certain perspective, the European Union can be seen as a mix between a broad expansion of supranational integration and classical intergovernmental cooperation between sovereign states. The sustainability of a gray area between supranationalism and intergovernmentalism is the main difference between multi-level governance and some integrative theorie.

Governance does not elucidate the issue of state sovereignty but merely asserts that a multi-level structure is forced by supranational and sub-national actors(Florina, ALPOPI, \& BURLACU, 2018).

Governance and governance are sometimes considered to be two faces of the same coin, and governance refers to the process of public policy engagement in which governmental authorities join others, and others representing different interest groups(Rădulescu, Bodislav, \& Burlacu, 2018). The relationship between government and governance can be considered the next type: Governance is what governments do, and governance is trying to explain and analyze how governments are doing its(Burlacu, Gutu, \& Matei, 
2018).

Governance reveals how governments co-operate with other social organizations but how they work with citizens to make decisions about important issues in society(Bran, Iovitu, \& Bodislav, 2017). The concept can be used in different contexts, such as: global, national, institutional or community.

The fundamental objective of multi-level governance is to apply all actors in governance and decision-making, whether they are national governments, interest groups, regional or local authorities, community institutions, or even civil society.

\section{Multi-level Governance at EU Level}

The European Union is interpreted by multi-level governance as a political system with institutional interconnections at different levels: European (supranational) European Commission, European Council and European Parliament - Court of Justice, Court of Auditors and European Central Bank

\subsection{Supranational actors}

Multi-level governance is a coordinated action of the Union, the Member States and local and regional authorities, based on partnership and aimed at developing and implementing the policies of the European Union. This involves the joint responsibility of the authorities at different levels of power concerned and is based on all sources of democratic legitimacy and on the representativeness of the various actors involved.

At the supranational level, the main actor is the Commission - the EU government - its established position is causing tensions both on the part of the national states and the Parliament wide competences in the legislative sphere being the only institution with legislative initiative. The proposals its legislative proposals are the input of the Parliament and the Council of the Union, as the proposals reach the Commission as recommendations of the working groups and, before being approved by the Council, the projects are examined by COREPER. Decisions taken at EU level represent the Community's interests synthesized either by combining or by transforming the interests of Member States or regions. With the agreement of the Member States, there were some mechanisms to limit the Commission's power.

The Commission plays an important role in the restructuring of the political system at European level, its actions being convergent with the interests of particular types of actors: on the one hand, the territorial collectivities - the sub-national actors, on the other hand the functional collectivities - the different transnational groups of interests.

\subsection{European Central Bank - Euro Zone}

The ECB is a supra-state body independent of both the governments of the member countries and the EU - it is the only one authorized to authorize the issue of the currency.

The European Central Bank manages the euro and draws on and implements the EU's economic and monetary policy. Its main purpose is to maintain price stability, thus supporting economic growth and job creation. 


\subsection{What does BCE do?}

- Fixes the interest rate at which it lends to commercial banks in the euro area, thus controlling money supply and inflation.

- Manage foreign exchange reserves in the euro area, as well as buy and sell currency to balance exchange rates.

- Ensure that financial institutions and markets are adequately supervised by national authorities and that payment systems are functioning properly.

- Guarantee the security and solidity of the European banking system.

- Authorizes the printing of euro banknotes by euro area countries.

- Monitor price developments and assess the risk that this may pose to price stability.

The ECB has the following three decision-making bodies:

- The Governing Council: is the main decision-making body. It is made up of the Executive Committee and the governors of the zero-zone central banks.

- Executive Committee: manages the ECB's day-to-day activities. It consists of the President and Vice-President of the ECB and four other members nominated by the leaders of euro area countries.

- The General Council has a consultative and coordinating role. It consists of the President and Vice-President of the ECB and the governors of the central banks of all Member States.

The ECB cooperates with the central banks of all the Member States of the European Union. Together they form the European System of Central Banks. The ECB coordinates cooperation between euro area central banks.

\subsection{National actors}

National governments maintain an important decision-making role, and control is not located at supranational level. National sovereignty is dilated in this decisionmaking process, and supranational institutions are autonomous.

The state powers are:

a. Executive or Executive - represented by the President, Government, Ministries. It proposes, often decides and implements the guidelines of public policy and the rules to be respected by citizens. The president, elected for five years by direct universal suffrage, appoints the Prime Minister and the government members proposed by the Prime Minister.

b. Jurisdiction - made up of judicial tribunals, administrative and financial jurisdictions or assimilated jurisdictions. They supervise the proper enforcement of the rules, settle the litigation, and decide which repairs are granted.

c. Legislative power or Legislative - Represented by Parliament.

\subsection{Regional actors}

The increase in the EU's regional importance was mainly determined by the increase in the Structural Funds budget. This concept aims at reducing disparities in the level of development of the regions, supporting the remaining regions and diminishing the discrepancies that separate them from the developed regions of the EU.

Regional development policies pursued in recent decades by European countries have 
been aimed at relaunching local economic and social development, economic recovery of less developed areas, and narrowing the gap between the levels of development of the regions.

The regionalization action taking place in Europe is the result of an ensemble of phenomena and activities that lead to the formation of regions on a territory, the forms of regionalization in the European states being in correspondence with the political and administrative realities existing in the European countries.

\section{Decentralization - The Process}

Decentralization is the term commonly used to transfer power (only a certain part) from the central to the other levels: the essence of decentralization is the transfer of articles of various central authorities to authorities operating in administrative-territorial units and even local authorities. By decentralization, the public administration becomes more efficient and more operational, the problems that concern the population are no longer bent in the ministerial offices, but they are solved at a lower level, in terms of opportunity and increased operability.

Decentralization allows the removal of certain public services of local interest or special areas of activity from the powers and central authority and transferred to the responsibility of local public administration authorities. The respective authorities enjoy some independence from the central power, having their own patrimony, stand-alone organization and have the freedom to act autonomously.

In the European Union, an important role in territorial development policies has begun to have its regions through participation in the decision-making system at different levels of jurisdiction.

Decentralization is a first step towards regionalization.

Regionalization is a long-term process where the state introduces a second level of government. This reflects an increasing tendency to identify institutions with a region, but this idea and those institutions remain extremely heterogeneous from one country to another. The term regionalization has become broader and means a process that creates a capacity for actions to develop a specific geographic area.

The term regionalization refers exclusively to administrative-territorial reorganization.

There are 5 types of institutional frameworks in the regionalization process:

- administrative regionalization

- regionalization through existing local governments

- regional decentralization

- regional autonomy

- regionalization through federal entities (Member States of a federal state)

So, regionalization is not always homogeneous. A state may know, on its entire territory, several forms of regionalization, depending on the issues to be addressed and the particularities that it must take into account.

Currently, regionalization is a general trend of local government. In the EU countries the issue of regionalization has become current under the influence of three factors:

1. the restoration of democracy has prompted a strong will to adopt the institutional 
standards of the European countries (regional reforms have changed the governing system in many European countries);

2. the growing importance of EU regional policy has prompted the initiative to establish or strengthen regional institutions as a way to improve compliance with EU requirements with the prospect of a possible partnership;

3. the transition to a market economy and recent economic recovery have caused discrepancies between capital cities and less-favored economic regions and between cities and villages.

This requires active development of regional development policy and institutional support at regional level.

To a certain extent, regionalization is part of the decentralization program taken over by all EU countries after the fall of communist regimes. Decentralization was necessary both for democracy and for improving the public management system. The first step was to restore self-government at municipal level.

The main areas of competence at regional level are:

1. Education (construction, equipment and maintenance of high schools);

2. Permanent professional training and apprenticeship;

3. Development and planning;

4. Planning, the environment and the heritage of cities (eg regional parks);

5. Transport (organization, financing, road-rail).

\subsection{The Importance of Regionalization and Decentralization}

Regionalization means the desire to achieve a balance of economic development by raising the level of less developed areas. Decentralization is the main benefit of it, making local and regional governments stronger and supposed to have increased their capacity to apply and formulate policies.

These are extremely important for the evolution of the political system, as it allows a better use of local, material and human resources in the interests of local communities.

\section{Causes of Multi-Level Governance}

Governance at supra-national and national level through the Union's institutions has denied the importance of those on which Community policies are being addressed. Without cooperation with the national level, the other two levels would not have been able first of all to develop the policies that were really necessary for the development of the Union and, moreover, they would not have been able to implement them because they would have been hit by the opposition of domestic actors;

Relationships between the various existing actors at one time could not be born nor would they be able to be stable if the institutions did not create a system in which these relations exist, defining them and coordinating the cooperation between the different levels of government;

The European Union is one of the world's most prosperous economic areas, but the differences between its Member States are striking, so there is a need to reduce the gaps between poorer areas and its more prosperous areas.

Consequences and effects of multi-level governance: 
1. Creates, due to the newly created relationships and interactions at different levels, complex models, the dominant functions being transactional and cooperative;

2. Decision-making powers, but also implementation of Community legislation, no longer only concern the national level of government but are shared between different actors at different levels, thus increasing the role of local authorities within the Union;

3. Defines a new feature of European cooperation, namely that the barriers imposed by the executive have been overcome and that there is an interaction of actors from different "arenas" in identifying and solving common problems through co-operation and coordination, resulting in joint decision making binding;

4. The central institutions will no longer intervene in matters of public interest, the citizen only addresses the institutions in his immediate vicinity.

The Lisbon Monitoring Platform (EUROPA 2020 Monitoring Platform) of the EU's local and regional authorities consists of observing territorial development, reflecting the views of members in the EU's political debate.

PM EUROPA 2020 (formerly the Lisbon Strategy Monitoring Platform) is a CoRmanaged network of 113 local and regional authorities from all EU Member States and has the following objectives:

1. Supporting the Committee of the Regions' advisory work on how to develop and implement the EUROPA 2020 strategy from the point of view of multilevel governance;

2. Reflecting the point of view of EU local and regional authorities in

3. The key EU decisions on sustainable development and employment and their implementation;

4. Exchange of experiences and best practices in all areas related to the Europe 2020 Strategy.

5. Regarding the main themes of the political debate surrounding the EUROPA 2020 Strategy and the CoR's consultative work on them, PM EUROPA 2020:

6. Conducts surveys and consultations among EU local and regional authorities on priority policy issues of the EUROPA 2020 Strategy, the results of which are reflected in the drafting or monitoring of the CoR opinions;

7. Since 2006, organizes the annual "Territorial Dialogue" event, where political representatives of the Member States are discussing the results of the Monitoring Platform's work with European Commission representatives and the Council Presidency; 8. Organizes workshops to discuss policy issues related to the implementation and monitoring of the Europe 2020 Strategy;

9. Through its website and the electronic newsletter EUROPA 2020 Brief, it systematically provides basic news and documents on the design and implementation of the EUROPA 2020 Strategy and related to the work of the platform and the planned events, as well as areas with limited access, where members can exchange information on specific topics, cooperate to prepare documents and prepare meetings.

\section{Integrated Development Policies}

Cities are geographical concentrations of human activities and interactions. These are the engines of the European economy, providing jobs and services, and acting as a catalyst for creativity and innovation across the EU. About $70 \%$ of the EU's 
population lives in an urban area, and these areas generate over two thirds of EU GDP. However, a series of permanent problems such as unemployment, segregation and poverty, as well as strong environmental pressures, are extremely acute. Therefore, policies for urban areas have a greater significance for the EU as a whole.

It is increasingly evident that the various challenges facing urban areas - economic, climate, social, demographic and environmental - are closely linked and urban development success can only be achieved through an integrated approach. Consequently, measures for physical renovation of urban areas should be combined with measures that promote education, economic development, social inclusion and environmental protection. In addition, an indispensable aspect concerns the development of strong partnerships involving local citizens, civil society, the local economy and the various levels of governance. Combining local capacities and knowledge is essential for identifying common solutions and delivering widely accepted and sustainable outcomes.

Such an approach is particularly important at this time, given the seriousness of the challenges currently faced by European cities. These challenges range from specific demographic changes to the consequences of economic stagnation in terms of job creation and service provision as well as the impact of climate change. Finding effective responses to these challenges will be crucial to achieving the goal of a smart, sustainable and inclusive society, as set out in the Europe 2020 strategy.

\section{Conclusions}

European Grouping of Territorial Cooperation (EGTCs) are concentrated in certain areas, especially along the Hungarian, Slovak, French, Spanish and Portuguese borders. Their territorial coverage is particularly extensive in Hungary. Some Member States are not involved in any EGTC, in some cases these differences being due to other types of already established cooperation structures.

In 2017, four EGTCs had members from a third country. Since the EGTC Regulation did not explicitly refer to EGTCs as having an external dimension until it is modified, we cannot expect a rapid occurrence of such EGTCs.

The main types of EGTCs are:

- Cross-border EGTCs, which mainly address local and regional challenges;

- Transnational EGTCs serving far more extensive territories than cross-border cooperation areas;

- Networked EGTCs, made up of members who are not connected to a particular area and

- EGTCs for specific purposes, eg hospitals, natural parks, transport corridors and universities.

Until December 31, 2017, there were 68 EGTCs in total. The most common structure among EGTCs involves the cooperation of between 2 and 20 local authorities with small and medium-sized cooperation structures. The second important structure is crossborder cooperation involving regional authorities.

EGTCs are mostly funded through membership fees, national and regional budget transfers and contributions from EU funds, in particular from the European Structural 
Funds and Investment Funds (ESI funds), but also from the LIFE + Erasmus + and Horizon 2020.

In 2017, EGTCs were active in restructuring due to the increase in membership: a total of $21(31 \%)$ reported a change in membership.

At the end of 2017, more than 20 new EGTCs were being set up. Therefore, it is likely that the range of applications of the EGTC instrument will continue to expand.

Motivation and challenges related to the creation of EGTCs motivation:

1. The EGTC instrument has been created to facilitate and promote territorial cooperation to strengthen cohesion in the EU. EGTCs are widely used to strengthen and / or deepen cross-border (interdisciplinary) general cooperation. They are mainly used by local and regional bodies, but EGTCs are also used for interregional cooperation.

2. The rationale for setting up an EGTC varies. First, an EGTC is set up as a visible and permanent structure for territorial cooperation to manage common projects, infrastructures or environmental resources.

EGTCs contribute to:

- reinforcing an integrated strategic approach;

- stabilizing cooperation structures and ensuring continuity of actions;

- improving the transparency and visibility of cooperation; and

- facilitating participation in EU programs.

The challenges in terms of creating EGTCs are:

- the lack of experience and knowledge of the approval authorities with regard to the actions to be taken;

- the need to reach an agreement between EGTC members on the content of the work or the precise tasks involved; as well as different national rules and regulations, such as service acquisitions and taxation.

The EGTC Regulation provides for a European legal form that is subject to national implementing rules, so that customized solutions based on applicable national legislation are found for each EGTC.

\subsection{EGTCs and European Territorial Cooperation}

The initial objective of the EGTC instrument was to facilitate European Territorial Cooperation (ETC) both at program and project level, which, in addition to the implementation of specific projects, includes programming in a broader sense.

Two EGTCs are currently implementing ETC programs: the GECT Grande Région, which is the managing authority for the Grande Région program; and ESPON EGTC, which has a specific role because it is a unique beneficiary and as such is responsible for the implementation of the ESPON 2014-2020 program.

Some EGTCs are responsible for the implementation of small project funds under the specific ETC programs: EGTC RDV and EGTC Via Carpatia manages the small project fund in their respective geographic areas within the Interreg Hungary-Slovakia program. Two EGTCs are unique beneficiaries of ETC projects, and EGTC GO implements an Integrated Territorial Investment (ITI).

In 2017, 33 EGTCs were involved as main partner or partner in approximately 83 ETC projects. EGTCs are involved in the ETC and other ways, eg by co-financing or 
facilitating ETC projects or programs.

\section{References}

Bran, F., Burlacu, S., \& Alpopi, C. (2018). Urban Transport of Passengers in Large Urban Agglomerations and Sustainable Development. Experience of Bucharest Municipality in Romania. European Journal of Sustainable Development, 7(3), 265-273.

Bran, F., Iovitu, M., \& Bodislav, D.-A. (2017). GLOBALIZATION AS EMPOWERMENT TOWARDS ECOLOGY. In Pascu, LF and Lehr, CB and Tiron, $\mathrm{O}$ and Vasile, GG (Ed.), 20TH INTERNATIONAL SYMPOSIUM - THE ENVIRONMENT AND THE INDUSTRY (SIMI 2017) (pp. 318-324). https://doi.org/10.21698/simi.2017.0041

Burlacu, S., Gutu, C., \& Matei, F. O. (2018). Globalization - Pros and cons. Quality - Access to Success.

Florina, B., ALPOPI, C., \& BURLACU, S. (2018). Territorial Development-Disparities between the Developed and the least Developed Areas of Romania. LUMEN Proceedings, 6(1), 146-155.

Rădulescu, C. V, Bodislav, D. A., \& Burlacu, S. (2018). DEMOGRAPHIC EXPLOSION AND IT GOVERNANCE IN PUBLIC INSTITUTIONS. Managerial Challenges of the Contemporary Society. Proceedings, 11(1), 18.

Best, E., Christiansen, T., Settembri, P. (2008) The Institutions of the Enlarged European Union, London: Edward Elgar Publishing.

Bodislav, D.A. (2012) 'The New Economy: Efficiency, Equity and Sustainable Economic Growth', Quality Access to Success, no. S1, 21-27.

Bodislav, D.A., Bran, F., Popescu, L.M. (2018) ,The Business Automated Data Economy Model, 2018 Early Update', Quality - Access to Success, no. S1, 80-84.

Bran, F., Bodislav, D.A., Radulescu, C.V., Ioan, I. (2014) ,Corporate Governance Intervention for a Sustainable Socio-Economic Model', Revista de Cercetare și Intervenție Sociala, no. 46, 216-226.

Cosman, O. (2018) 'Romania and innovation in comparison with the rest of EU countries. Where we are', [Online], [Retrieved January 23, 2019], https://start-up.ro/tabloul-de-bord-european-privindinovarea-2018/?fbclid=IwAR3liAtuVK1EKIVoacX9916e6JgvJNxzqYxxY9M4rrtEPH6YayQUTAGo3k

European Commission - Directorate General Regional Policy (2010) 'Measuring the quality of government and subnational variation', [Online], [Retrieved January 23, 2019],https://ec.europa.eu/regional_policy/sources/docgener/studies/pdf/2010_government_1. pdf

EUROSTAT (2018). 'Gross domestic expenditure on Research and Development, 2006 - 2016', [Online], [Retrieved January 23, 2019], https://ec.europa.eu/eurostat/statisticsexplained/index.php/R_\%26_D_expenditure

Sandache, S. (2017). 'Fiscal facilities for research and development: Companies could benefit of a ten year tax holiday', [Online], [Retrieved January 23, 2019], https://www.capital.ro/facilitati-fiscalepentru-cercetare-dezvoltare.html

*** 'The concept of multilevel governance', [Online], [Retrieved January 23, 2019], http://www.rasfoiesc.com/legal/administratie/stiinte-politice/Conceptul-guvernanteimultiniv39.php 